\title{
CHILDREN IN ADULT TELEVISION WORLD: THE IMPORTANCE OF MEDIA LITERACY IN FAMILY VIEWING HABIT
}

\author{
Tribuana Tungga Dewi, Muhammad Jaka Permana \\ Fakultas Ilmu Komunikasi, Universitas Pancasila Jakarta \\ tribuana.suryokusumo@gmail.com,muhammadjakapurnama@gmail.com
}

\begin{abstract}
Children are specific target audience group that has different characteristics with adult. If an adult has the ability to think logically and to communicate verbally, most children are lack of these skills. This condition is normal in human development stages, but for today's highly competitive television industry children are in danger on absorbing programs that is not suitable for their developmental stage. In this case, parents have to accompany and supervise their children's television viewing habit. This research conducted in Perumahan Gandaria Town House, Jakarta by in-depth interview and observation. In-depth interview gathered data from parents point of view on how they develop television viewing regulation in their house. While observation conducted in order to gather data on the children's viewing habit. As a result, we found that parent in each family already has television viewing regulations in their house. This regulation supposedly will able to guide and protect the children while watching television. But other finding shown, parents themselves are the one who broke the regulations. Through observation, evidence shown that children watch adult or teenagers television programs not by their own choice, but by their parents choice. It is important to recommend parents to have better understanding on basic media literacy skill, so they can guide and accompany their children to be able to choose the most suitable programs for them. By accompanying and guide their children while watching television, parents are also allowed their children to build critical thinking and prepare them to have basic media literacy skills.
\end{abstract}

Keywords: children, parenting, television, viewing habit, media literacy. 


\section{INTRODUCTION}

\section{Media Literacy; Why Matters?}

In Indonesia, television is still one of the mass media that frequently choose for children. A research conducted by Yayasan Pengembangan Media Anak (YPMA) in 2006 found that elementary school students watch television approximately 30-35 hours a week or 4-5 hours a day (Retrieved from www.kidia.org, 04/04/2016). This finding considered as too much consumption on screen media (television and video games).

Children always be a vulnerable target audience in media industry. Piaget in Drewes and Schaefer (2010) explained most children below 11 year old have not develop their skill to think in abstract and logical way. In today's vast saturated media environment it is impossible to banned children from media consumption, but yet still possible to draw strict guidelines on how the media consumption should apply in our home. Since children are not develop well in their logical thinking, parents will play an important role for setting up boundary on children media consumption.

Based on these facts we conducted an exploratory research on how four families in Gandaria Town House, Jakarta develop their television viewing regulation at home. Television viewing regulation not only important to protect children from the negative impact on television, but also suitable to develop critical thinking and self-regulation for audience. A child might not able to have critical thinking and self-regulation yet, but rather exercising this skill when they grow older it would be best to train them with basic critical thinking, while they still at the early stage of development. The simple steps might help them to grow as a smart and critical television viewer. This ability to be a smart media audience is what known as media literacy.

Back then literacy only applied to print media. When someone able to read and write then they already considered as literate. But then, it is expanded to other media. The National Telemedia Council as quoted in Silverblatt (2014), defines media literacy as "the ability to choose, to understand-within the context of content, form/style, impact, industry and production-to question, to evaluate, to create and/or produce and to respond thoughtfully to the media we consume. It is mindful viewing, reflective judgment." This definition is explained more by Ewen, quoted in Baran (2014) mentioned, "...Literacy was about crossing the lines that had historically separated men of ideas from ordinary people, about the enfranchisement of those who had been excluded from the compensations of citizenship." While Silverblatt (2014) consider that media literacy promotes the critical thinking skills that enable people to make independent choices with regard to 1) which media programming to select and 2) how to interpret the information they receive through the channels of mass communication. 
In this research we determine that media literacy in the family, supposedly starts with a simple practical step: Setting up regulation on daily media consumption, including accompanying children while they consume media content. We specifically focused on television viewing habit because in the four families we observed, television is their primary media.

\section{METHOD}

In order to gather the data, In June 2016 we conducted in-depth interview to both parents in each family and observed the family television viewing habit. Children that involved as observational objects are between 5 to 12 years old.

\section{RESULT AND ANALYSIS}

\section{Regulation in the Family; Who Involve and What They Determine?}

Through interview, we found that all four families admit (and also confirmed by our observation data) they already settled regulation on television viewing habit though each has different boundary. The key findings showed all parents aware the importance of regulations on television viewing habit to a certain extend. All the regulation are not written, but only socialize in a spoken basis.

Setting up regulation in all families conducted by the parents. Children are only the one who must obey the rules. The regulation in all family, typically regarding to duration of watching and program genres that are allowed for the children to watch. In these two fields, we found that sometime the one that broke the rule are the parents. For example, based on our observation we found that the children in one family watch a television drama (sinetron) for adult because the mother watched it. The mother seemed do not mind and discussed what was on the program with her child.

Most of the time, there will be adult to accompany the children while watching television. Mother plays an important role in this part, since in all families we observed mother are the primary caregivers. All parents also aware the importance of adult to be there when the children are watching television. They also seemed to build discussion with their kids while watching television. In some families, the children are the one who ask more on what they saw in the programs. Especially, when the program is not the suitable one for them. The importance of mother as primary adult that accompany children while watching television also shown through interview with the fathers. All fathers seemed to answer with uncertainty about their children's television viewing habit. Some also stated clearly that the mother are the one who is more active on accompanying their children while watching television. 
Another finding in the research is that most of the time, watching television is an activity that is done while doing other activities. Watching television seemed to be a favorite activity while eating. Some families feed their children breakfast and lunch in front of television. In the morning watching television also common while getting ready for school. In observation, we found what is consider as "accompanying the children", not always really mean watching television side by side and discussing what is on the programs. Frequently we saw parents are around their children while watching television, but they are doing some other work. Cleaning the house, preparing for food, are some activities that commonly done by the parents while their children watching television.

What is interesting is that all parents realize the importance of watching television with the children. They consider watching together with the children is the momentum for discussing many things with their children. Each family chose different program type, but all prefer programs with entertainment genre. This finding shown that television can be functioned as an integration tool for the family, the media that can integrate discussion between the older and younger generation. Thus, television programs might also be use for the families to transfer family value by discussing what is consider suitable and not suitable for them. Watching together with the family is a good start for parents to train their children to be ready for participate as a media literate audience that not only positioned as consumer but more as an active audience. As an active audience, we will be able to ignore the under qualify television programs and might also push the industry to produce, distribute and exhibit only high quality programs to the audience.

\section{CONCLUSION}

With a limited amount of informant, we conclude that in these families television still plays an important role. This important role lead parents to settled regulation regarding television viewing habit. This is a good start, though children are not contribute on the settlement of the regulation. In the future, more parents need to be aware of their children's contribution on settling up a television viewing regulation. Letting children contribute to develop the regulation, means that the adult are preparing their children to be the active audience that can think critical. Critical thinking is a must have skill for every children to be a media literate audience.

But it is important to remember that parents play a very important role on preparing their kids to be a media literate audience. In our finding we found though parents already realize how important regulation on television viewing habit, but there is a tendency that parents themselves are not always the one that already fully ready to be categorize as active audience. This finding leads us to a conclusion that what is urgent to execute is an integrated media literacy workshop that include parents, other caregivers, and children 
as a future active audience. This workshop should include multi-disciplinary experts (media production specialist, family psychologist, psycho-analysis therapist, teacher, etc) with experiential learning workshop method.

Since mothers play an important role as the primary caregiver, we recommend to conduct a special interactive seminar or workshop for mothers. This activities can be perform in a setting that most comfortable for the mothers, such as arisan or religious services (pengajian or kebaktian). The purpose of the activities to be inserted in a regular woman gathering events, because in some cases women are most comfortable when a new activitt conducted within their circle of friends.

We realize the limitation of this research is on the limited amount of informant and time. We are planning to expand this research with a bigger informant or even with a survey as a data collection technique, so more description on television viewing habit can be provide.

\section{REFERENCES}

Baran, Stanley. (2014). Introduction to Mass Communication; Media Literacy and Culture. New York; McGraw Hill.

Drewes, A.A and Schaefer, C.E. (2010). School-Based Play Therapy. New Jersey; Wiley \& Sons, Inc.

Silverblatt, Art. Smith, Andrew. Miller, Don. Smith, Julie. Brown, Nikole. (2014) Media literacy: Keys to Interpreting Media Messages. California, Praeger. 